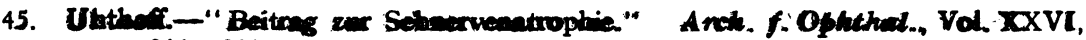
p. $244,1880$.

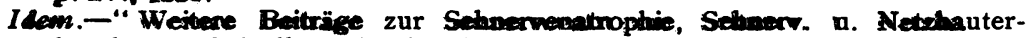
krankungen bei Allgemeinerkrankung," Verbag von H. Peters, Bertin.

Idem.-Graefo-Sweminch. Vol. XI, 1903.

46. v. Grosz.- " Die Atrophie der Optiknsnerven bei Tabes dorsalis." Ber. über den 9 intermat. Ophth.-Khomgr. in Utrecht, 1899.

47. จ. Striimpell.- "Die pathologiscbe Amabomie der Taber." Anch.f. Psych., Vol. XII, p. 723, 1882.

Ideen.-New rol. Cemiralbl. Vol. VIL, p. 1221888.

Idem.- "Beiträge zur Pathologie des Rückenmarks." Arck. f. Psych. u. Nervenke. Vol. XI. pp. 27 and 723.

Idem.-" Lehrbuch der speziellen Pathologie und Therapie." Leipzig, 17th Anfl. 1909.

45. Wagenmann. - " Schwund markhaltiger Nervenisern in der Retina in Folge von genuiner Sehnervenatrophie bei Tabes dorsalis." Arck. f. Ophth., Vol. XL, p. 256, 1894.

49. Wilbrand and Sacieger.- " Nemrotogie des Auges," Vol. V. 1913.

\title{
BUTYN : A SUBSTITUTE FOR COCAIN
}

BY

W. M. Beaumont

BATA

THE pre-eminence of cocain as a local anaesthetic is challenged by butyn. This synthetic product of ooal-tar was introduced by the Abbott Laboratories of Chicago for surface anaesthesia, especially in ocular, nasal, pharyngeal and dental diseases. Its chemical formula is para-aminobenzoyl gamma di-n-butylaminopropanol sulphate.

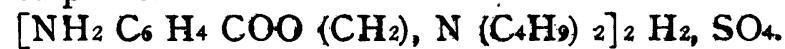

The chemical research work was done by Profs. Roger Adams and Oliver Kamm, of the University of Illinois, and Dr. E. H. Volveiller, of the Abbott Laboratories.

Butyn has been reported on by a committee on local anaesthesia appointed by the section of Ophthalmology of the American Medical Association. The members were :-Albert E. Bulson, Jun., Fort Wayne (Chairman); Wm. Zentmayer, Philadelphia; Roger S. Thomson, New York City; H. Maxwell Langdon, Philadelphia ; Harry S. Gradle, Chicago.

Their report* shows that one minute after one instillation of 2 per cent. solution surface anaesthesia is sufficient to permit the removal of foreign bodies from the cornea without discomfort. Anaesthesia lasts from 15 to 20 minutes, or it may be $\mathbf{3 0}$ minutes. The depth of anaesthesia is not sufficient by one instillation for operations or for removal of deeply imbedded foreign bodies in the cornea, but it is sufficient for the application of astringents and

- Journal of the American Medical Association, February 4, 1922, p. 343. 
for the determination of intraocular pressure with the tonometer. When a number of instillations have been made there is marked increase in the depth, duration and degree of the anaesthesia. For operative work (as with cocain) four instillations, 3 minutes apart, are sufficient. Operative work is to be begun from 5 to 10 minutes after the bast instillation. The anaesthesia which results is sufficient for all the commoner major operations except enucleation, which has not been tried. The height of anaesthesia is reached in 5 to 8 minutes after the fourth instillation, and its duration lasts from 20 to 30 minutes, or even nearly an hour.

Side actions.- One instillation almost always produces a mild hyperaemia of the conjunctiva, not increased by subsequent instillations. It is controlled by epinephrin solution.

Butyn does not affect the pupil diameter, nor increase the ocular pressure. There is no desiccation or disturbance of nutrition of the cornea. A solution of butyn does not deteriorate rapidly when exposed to the air and light, nor is it impaired by boiling. In no instance, including hundreds of times that butyn has been used by members of the Committee, for minor and major eye operations, as well as in operative work in the nose and throat, have the slightest systemic toxic manifestations been noted. It has also been used for surface and infiltration anaesthesia, and in paste for topical application in nose and eye work, without toxic effect.

"Our Committee is unanimous in the opinion that butyn for surface anaesthesia for minor operations is superior to cocain." It acts more quickly, fewer applications are required, there is no dilatation of the pupil or desiccation of the cornea and anaesthesia is more profound. For iridectomy and cataract extraction there is a more profound anaesthesia than occurs with cocain. For operations on the extrinsic muscles the results are equal to cocain, although the Committee believes that a stronger solútion than 2 per cent. may be preferable. For infiltration anaesthesia, using both a 0.50 and 1 per cent. solution, the Committee has had "very satisfactory results."

Conclusions :-

(1.) Butyn is more powerful than cocain, a smaller quantity being required.

(2.) It acts more rapidly than cocain.

(3.) Its action is more prolonged.

(4.) It is less toxic.

(5). There is no drying effect on the tissues.

(6.) There is no change in the size of the pupil.

(7.) There is no ischaemic effect and therefore no shrinking effect on the tissues.

8. It can be boiled without impairing its efficiency. 
Butyn compared with other local anaesthetics. Butyn is $2 \frac{1}{2}$ times more toxic than cocain when injected hypodermically into albino rats, but in cats the effects are about equal.

In a preliminary report of the Council on Pharmacy and Chemistry of the American Medical Association, ${ }^{*}$ it is stated that on the normal human eye a 0.50 per cent. solution of butyn is less efficient than a 1 per cent. solution of holocain, but more efficient than a 1 per cent. solution of cocain, or a 1 per cent, solution of eucain. Butyn solutions are non-irritant. Like alypin, butyn is not mydriatic, and it does not affect the accommodation. It may take the place of cocain for surface anaesthesia of mucous membranes. It is superior for use in the eye to other synthetic anaesthetics for the reason that it can be used in lower concentrations (presumably because of more prompt absorption).

On the other hand butyn is not promising for injection or spinal anaesthesia since its toxicity is greater than that of procain.

The following table shows the comparative efficiency of butyn compared with procain and cocain :-

\begin{tabular}{|c|c|c|c|c|c|}
\hline & & $\begin{array}{c}\text { Efficiency } \\
\text { on Motor } \\
\text { Nerves. }\end{array}$ & $\begin{array}{c}\text { Efficiency } \\
\text { on Sensory } \\
\text { Nerve } \\
\text { Trunks. }\end{array}$ & $\begin{array}{c}\text { Efficiency } \\
\text { on Rabbits' } \\
\text { Cornea }\end{array}$ & $\begin{array}{c}\text { Efficiency } \\
\text { on Frogs' } \\
\text { Skin. }\end{array}$ \\
\hline Cocain ... & $\ldots$ & 1 & 1 & 1 & 1 \\
\hline Procain & ... & 1 & $\frac{1}{2}$ & $\frac{1}{5}$ & $\frac{1}{8}$ \\
\hline Butyn ... & $\ldots$ & 8 & 2 & 1 & 2 \\
\hline
\end{tabular}

Butyn in dentistry has been used in the United States for extractions both by conduction and by infiltration methods. In the latter 1 c.c. of a 0.5 per cent. solution has been injected without producing toxic symptoms. But as its use by dentists is still in the experimental stage it is recommended that it should be used cautiously. The aphrodisiac effects of cocain which are sometimes noticeable after injections of the drug to produce local anaesthesia in dental practice $\dagger$ have not been recorded after the use of butyn.

My own limited experience of butyn confirms the clinical findings of the Committee appointed by the American Medical Association.

I have used it in 2 per cent. solution for the extraction of cataract and for iridectomy, with satisfactory results.

For the removal of foreign bodies in the cornea and conjunctiva

* Journal of the American Medical Association, December 10, 1921, p. 1,891.

$\dagger$ British Medical Journal, May 27, 1922. 
1 per cent. solution is usually sufficient to produce anaesthesia without causing conjunctival injection and there is never any mydriasis.

In the treatment of glaucoma if butyn is combined with eserin there is seldom any complaint of twitching or discomfort as is sometimes the case when eserin is used alone.

For all the everyday purposes for which cocain is used in ophthalmic practice butyn appears to be an ideal alternative and one which is devoid of the disadvantages of mydriasis and desiccation of the cornea. When used with other medicaments it is necessary to remember that butyn is incompatible with chlorides.

I have also used butyn as a lotion to relieve pain in herpes of the head and eye and in detachment of the retina.

In view of the widespread illegal administration of cocain, the potentialities of a substitute, devoid of attractions for the drugtaker, should be of value, and if further investigation confirms all that is claimed for butyn, we may hope that the results will have far-reaching effects in reducing the manufacture and repressing the distribution of a drug the illicit use of which causes social calamities.

\section{THE VISION OF RAILWAYMEN}

BY

\section{Leonard J. C. Mitchell, M.B., B.S. (Melb.)}

ASSISTANT EXAMINER IN VISION, ETC., VICTORIAN RAIL WAYS

IN order to arrive at some more definite relation between vision as tested by test types under good conditions, and what may be termed " safe vision" from a railway point of view, a series of tests was undertaken recently (1920) at Tottenham (Vic.). Previously (1898) Barrett, Orr and Murray had conducted similar tests, but their data were too meagre to give any definite result, and further, the main object before these experimenters was to prove that what is called a "practical test" is, by itself, very misleading. Later (1914) Gault, Webster and Ryan, in collaboration with Stanley and the writer, conducted a test with a special signal, but it would seem that fallacy was introduced by first reducing with glasses the vision of persons examined. The New South Wales Railway Medical Officers have recorded a test in which the persons examined had vision below normal, but the fallacy of their test was that there was a different background for the various signals used. Bearing in mind these unsatisfactory results, the Tottenham experiment was planned and carried out by H. R. Stanley and the writer, on the afternoon of a cloudy calm 